\title{
Occurrence of volcanic ash in the Quaternary alluvial deposits, lower Narmada basin, western India
}

\author{
RACHNA RAJ \\ Department of Geology, Faculty of Science, M. S. University of Baroda, Vadodara 390 002, India. \\ e-mail: naveenrachna@gmail.com
}

\begin{abstract}
This communication reports the occurrence of an ash layer intercalated within the late Quaternary alluvial succession of the Madhumati River, a tributary of the lower Narmada River. Petrographic, morphological and chemical details of glass shards and pumice fragments have formed the basis of this study. The ash has been correlated with the Youngest Toba Tuff. The finding of ash layer interbedded in Quaternary alluvial sequences of western Indian continental margin is significant, as ash being datable material, a near precise time-controlled stratigraphy can be interpreted for the Quaternary sediments of western India. The distant volcanic source of this ash requires a fresh re-assessment of ash volume and palaeoclimatic interpretations.
\end{abstract}

\section{Introduction}

The occurrence of Toba tephra has been reported mostly from the eastern and central parts of the Indian peninsula. Ash beds reported from the Quaternary sediments of the Son Valley of north central India (William and Royce 1982; William and Clarke 1984, 1995) are supposed to have been derived from Toba, northern Sumatra (Rose and Chesner 1987). Other Toba occurrences of Indian peninsula in recent years are along the Kukadi River at Bori, Maharashtra (Korisettar et al 1989), Son in the central Narmada valley (Basu et al 1989; Biswas et al 1989 and Acharyya et al 1993), Mahanadi and Brahmani River basins (Devdas and Meshram 1991) Goguparhu, Kareni and Guruwara (Acharyya et al 1993), Vansadhara and Nagavali River basins (Devdas and Meshram 1991), and Sagileru River basin, Andhra Pradesh (Acharyya et al 1993). This communication reports the occurrence of an ash layer quite similar to the Younger Toba Tuff (YTT), from the Quaternary alluvial sediments of the lower Narmada valley from the Madhumati River section near Tejpur (long. $73^{\circ} 18^{`} \mathrm{E}$, lat. $\left.21^{\circ} 46^{\circ} \mathrm{N}\right)$.

\section{The study area}

The study area forms a part of the tectonically active lower Narmada basin striding the seismically active Narmada Son Fault (NSF). NSF has a known history of tectonic activity during Tertiary and Quaternary (Chamyal et al 2002). Recent works have shown that in a reactivated sedimentary basin geomorphic evolution is due to combined interaction between tectonics and the sedimentation process (Jones et al 1999). The Madhumati, Amravati and the Kaveri Rivers are the three main tributaries of the Narmada River meeting at its southern bank (figure 1). A major part of the study area comprises Late Cretaceous-Eocene basaltic lava flows belonging to the Deccan Trap (figure 1), whereas towards the western part Tertiary sediments rest over the Deccan Traps. The NSF divides the Indian plate into two halves, trends in ENE-WSW direction and passes very close to the study area (figure 1). Geomorphologically, the lower Narmada basin is divisible into three zones. The upland zone consists of basaltic flows, a low highlands zone consisting of sandstones and conglomerates belonging to Tertiary and the third zone is the alluvial zone. The topography

Keywords. Toba; ash; Quaternary alluvial deposits; lower Narmada basin; western India. 


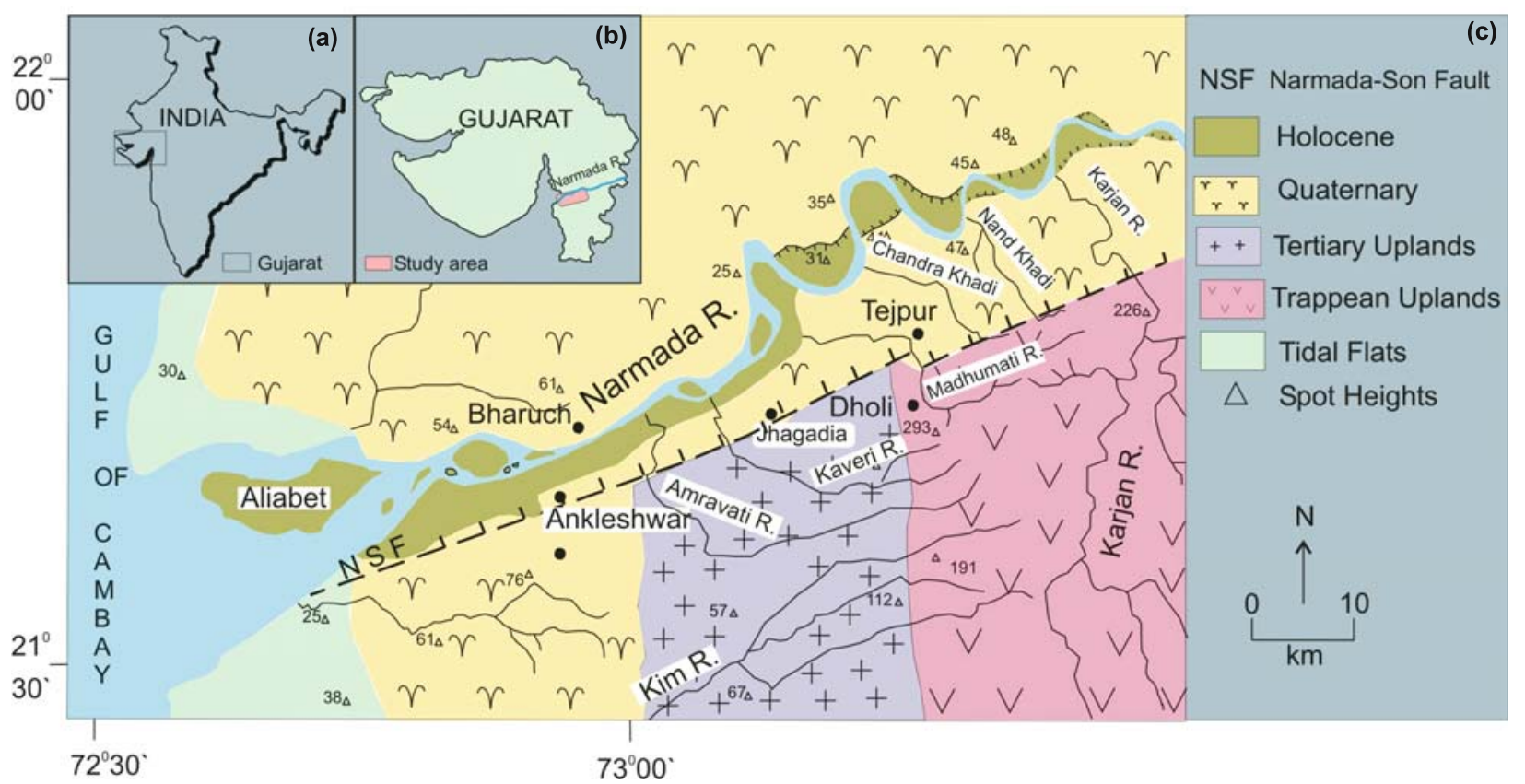

Figure 1. (a, b) Location map of the study area. (c) Figure showing the locality Tejpur where ash was discovered in the Madhumati River basin. Geology of the area is after Agarwal (1986) and Merh (1995).

of the upland is highly rugged and characterized by steep escarpments bounding the mesa tops and deep narrow gorges along the course of various streams (Chamyal et al 2002). Longitudinal valleys form the first order geomorphic feature in the upland zone. These valleys develop where the strike-parallel structural grain of the underlying geology dominates the topography. The valleys are aligned ENE-WSW following the trend of NSF. The low highland of Tertiary rocks exhibits hummocky topography and it is in conformity with the anticlinal folds and faults (Agarwal 1986). The study pertains to the Madhumati River basin, where two major geomorphic surfaces - the alluvial plain surface and the flat topped valley fill terrace have been mapped and termed as $S_{1}$ and $S_{2}$ surfaces.

\section{Lithostratigraphy}

The $S_{1}$ surface of Madhumati River basin at the locality called Tejpur, in the lower Narmada basin, exposes a $36 \mathrm{~m}$-thick Quaternary fluvial sediment succession along the banks (figure 2). The oldest exposed horizon of the succession is the matrix supported gravels, which is $3 \mathrm{~m}$ thick and the base is not exposed. The clasts are poorly sorted and are supported by poorly-sorted matrix of coarse sand and silt. The matrix-supported gravel is followed by an $8 \mathrm{~m}$ thick package of alternating cycles of horizontally laminated medium-to-coarse sand and gravel lenses. The clasts in the gravel lenses broadly fine upwards. This is overlain by a $0.4 \mathrm{~m}$-thick ash bed (figures 2, 3A, B), which can be traced over a distance of about $500 \mathrm{~m}$ in the succession. The ash is followed by a $20 \mathrm{~m}$-thick horizon showing cycles of finely laminated silty sand and gravel lenses. The succession is capped by $4 \mathrm{~m}$-thick silt horizon in which gravel clasts are embedded at places.

The gravely unit at the base is represented by the coarsest sediments (gravel, coarse sand and silt). Mass flow processes play a dominant role in the high energy conditions. The unit is interpreted to have been deposited by catastrophic, hyperconcentrated flows (Miall 1998) and in gravel-bed channels. Gravels that form the basal part of the sediment succession indicate high energy streams with prevalent bedload transport. The characteristics of matrix-supported gravel exhibit formation of this unit as by high strength debris flow (Miall 1996). The flow occupied pre-existing alluvial topography-occupy channel and assumed channelised form. This form is preserved when flow stops forward movement as a result of the development of internal friction due to loss of water (Miall 1996). The gravel lenses are crudely stratified and intercalated within sheet-shaped beds consisting of horizontally laminated coarse-to-medium sands. Settling from suspension is responsible for most of the other finer deposits of the section which go on decreasing in size towards the upper part of the unit. Two types of channelized transport can be distinguished (Miall 1996): through relatively deep channels and through braided streams. Currents in deeply incised channels are most common where 


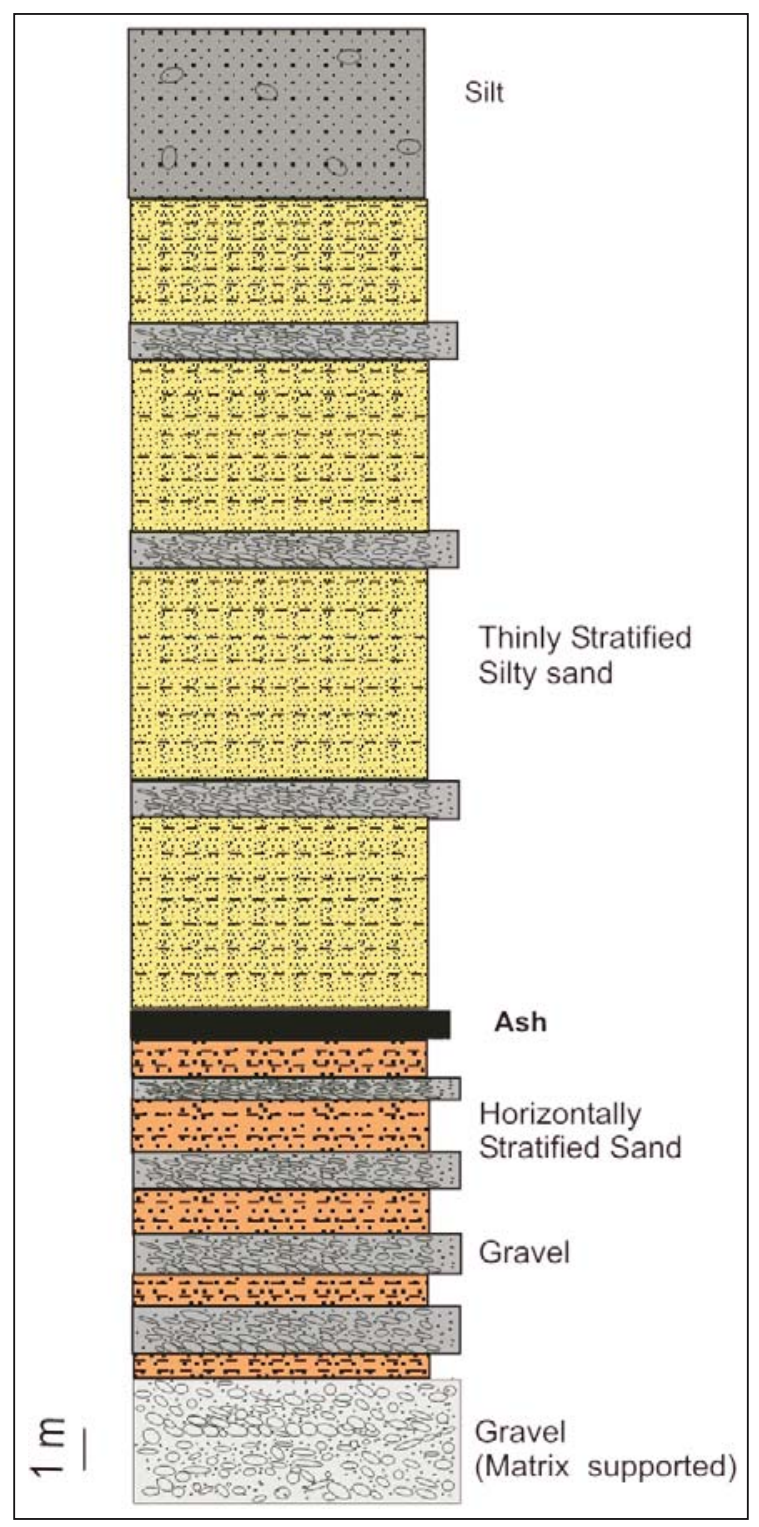

Figure 2. Lithology of sediment succession at Tejpur showing major units and position of ash.

sudden floods result in heavy, overloaded flows. Their deposits are found, in particular, in the lower part of the succession. Channels of these types are usually filled with a mixture of massive, badly-sorted gravels, resulting from accretion of coarse-grained sheets, where channels are truncated frequently. Other irregular channels are shallower and become filled almost exclusively with bars, dunes, plane beds and current ripples indicating lower flow intensity. Deposits of these types of channels occur predominantly in the middle part of the succession. Fine-grained sediments (mainly fine-grained sand to silt) are deposited from lowenergy (generally shallow, unchannelized) currents or by settling from suspension in abandoned channels, ponds and small lakes. They obviously
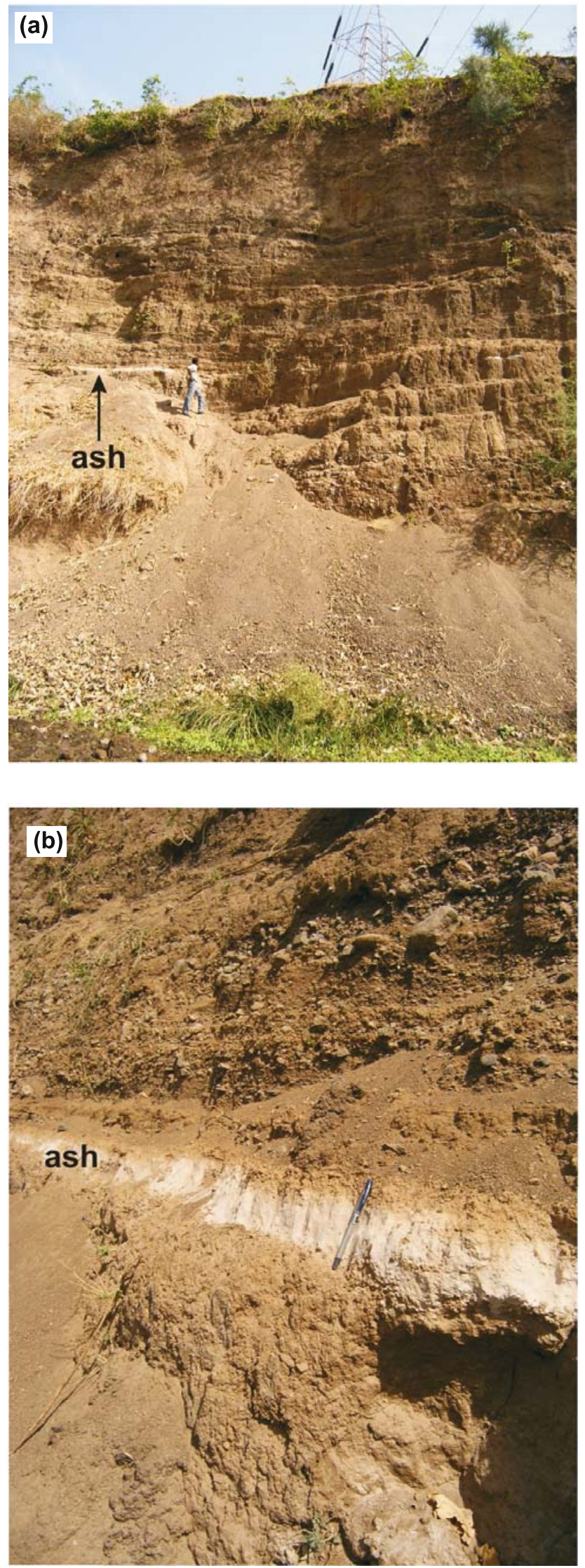

Figure 3. Photographs showing the cliff section in the Madhumati River at Tejpur. Note the position of ash unit, (a) distant view, (b) close view. 
represent hydrodynamic conditions from the lower part of the lower flow regime and standing water.

In the horizon above ash where the cycles of the fine grained silty-sand and gravel lenses are seen showing a fining-upward tendency, it can be interpreted as an effect of lateral shifting of sedimentary sub-environments, such as channels and overbank areas (Viseras and Fernandez 1995; Jo et al 1997) or channels and mass-flow areas (Calvache et al 1997). Each of the units is thinner and fine-grained than the underlying material. At places small-scale cycles form successions ranging from decimetres to some metres thick displaying a fining upward character. They owe their origin to the short term evolution of bed and channel forms controlled by changing hydrological conditions (Godin 1991). They consist commonly of a channel facies and represent waning flood deposits.

\section{Morphology and petrography of the Madhumati River ash}

The ash sub-unit occurs within the overbank silty sand units. It has sharp lower contact and an undulating upper contact following the pre-existing depositional topography. This sub-unit appears to be homogenous; however, at few places very fine laminations are discernible. The ash exhibits variation in colour from white in the basal part to light brown in the upper parts. The ash is unconsolidated, well-sorted, homogenous and friable to the extent of getting to fine powdery material. The overall grain size is less than $63 \mu \mathrm{m}$ and shows presence of dominantly angular to sub-angular glass shards in the samples within the size range of $63-15 \mu \mathrm{m}$. The ash material is light with its specific gravity being 2.39 and bulk density $0.2 \mathrm{gm} / \mathrm{cm}^{3}$. The glass shards make up $90 \%$ of the ash although pumice fragments are also present. Accessory minerals include quartz, felspars, biotite and occasional zircon. The details of the micro-structures of glass shard and pumice shard have been brought out very clearly by the SEM studies. The shape of glass shards ranges from blocky, cuspate, flat or platy, triangular, tri-radiate or multi-junctional (figure $4 \mathrm{a}, \mathrm{b}, \mathrm{c}, \mathrm{d}$ ). Most of them show a typical bubble wall structure, which is indicative of a magmatic type of eruption. At few places radial cracks are seen. The spongy pumice show fused spheroidal, irregular or pipe vesicles. At places rounded and sub-rounded pipe vesicles tapering at one end or elongated vesicles becoming bulbous at another end is also observed. Edges of many pumice surfaces are bladed. Glass shards on closer observation appear finely pitted or jagged. This may be attributed to the explosive nature of magmatic activity, i.e., when the ash fall is blasted high in the air where magmatic volatiles are largely dissipated causing quick chilling of the bubble surfaces (Karmalkar et al 1998). The percentage of bubble wall shard is more compared to pumice shards.

\section{Chemistry, REE signatures and ash correlation}

Chemical analysis of the ash sample was carried out at Wadia Institute of Himalayan Geology, Dehra Dun. One kilogram of each sample of bulk ash were collected and crushed to $250 \mu \mathrm{m}$. Out of the total $1 \mathrm{~kg}$ sample processed, about $100 \mathrm{~g}$ of each sample was ground to $75 \mu \mathrm{m}$ size for geochemical analysis. The major elements were analyzed by XRF (Siemens) on fused glass disc using method by Norrish and Hutton (1969). The trace elements were analyzed by ICPMS (Perkin Elmer SCIEX, Model: Elan DRC-e). Samples were digested in an open Teflon beaker using a combination of HF$\mathrm{HNO}_{3}+\mathrm{HClO}_{4}$ for the analysis of trace elements. The precision of analyses for major and trace elements including REE were monitored using USGS rock standard (SGR and MAG-1) and were better than $1.5 \%$ and $5 \%$ respectively. REE data were normalized with chondrite values after Masuda et al (1973).

The Tejpur ash is found to be rich in silica $\left(\mathrm{SiO}_{2}=71.15 \%\right)$ and $\mathrm{K}_{2} \mathrm{O}$ is low compared to $\mathrm{SiO}_{2}$ (table 1). It shows a lower light REE (La, Ce, Pr, $\mathrm{Nd}, \mathrm{Sm}$ ) and higher heavy REE (Ho, Er, Tm, Yb, $\mathrm{Lu}$ ) and a larger Eu anomaly (table 2, figure 5A and $\mathrm{B}$ ). The analyses given in table 1 for other localities, for the purpose of comparison are actually calculated to $100 \%$ on a volatile free basis. The water content of YTT of Indian occurrences given by Shane et al (1995) varies between 3.92 and $4.45 \%$ and in the samples of western continental margin by Pattan et al (2001) between 1.99 and $7.3 \%$. Schulz et al (2002) reported LOI values for YTT to be about $4 \%$. The total of the analyses at Tejpur is $97.4 \%$ (table 1 ).

The siliceous nature of the ash shows its unaltered state of preservation. High values of $\mathrm{SiO}_{2}$ and low values of $\mathrm{K}_{2} \mathrm{O}$ are in conformity with the values found for the ash in the Toba Caldera (Chesner 1998) and different Indian localities like Kukadi River (Karmalkar et al 1998), Son Valley (Basu et al 1989; Biswas et al 1989 and Acharyya and Basu 1993) and Narmada Valley (Shane et al 1995) (table 1). The values also fall very close to the values of glass shards from various northern Indian Ocean sites (Schulz et al 2002). Slightly higher values for the oxide of iron could be due to the $\mathrm{Fe}_{2} \mathrm{O}_{3}$ value in Tejpur sample of Madhumati River as compared to $\mathrm{FeO}$ values of Kukadi, Son, Guruwara, Narmada ash and Toba tuff of 

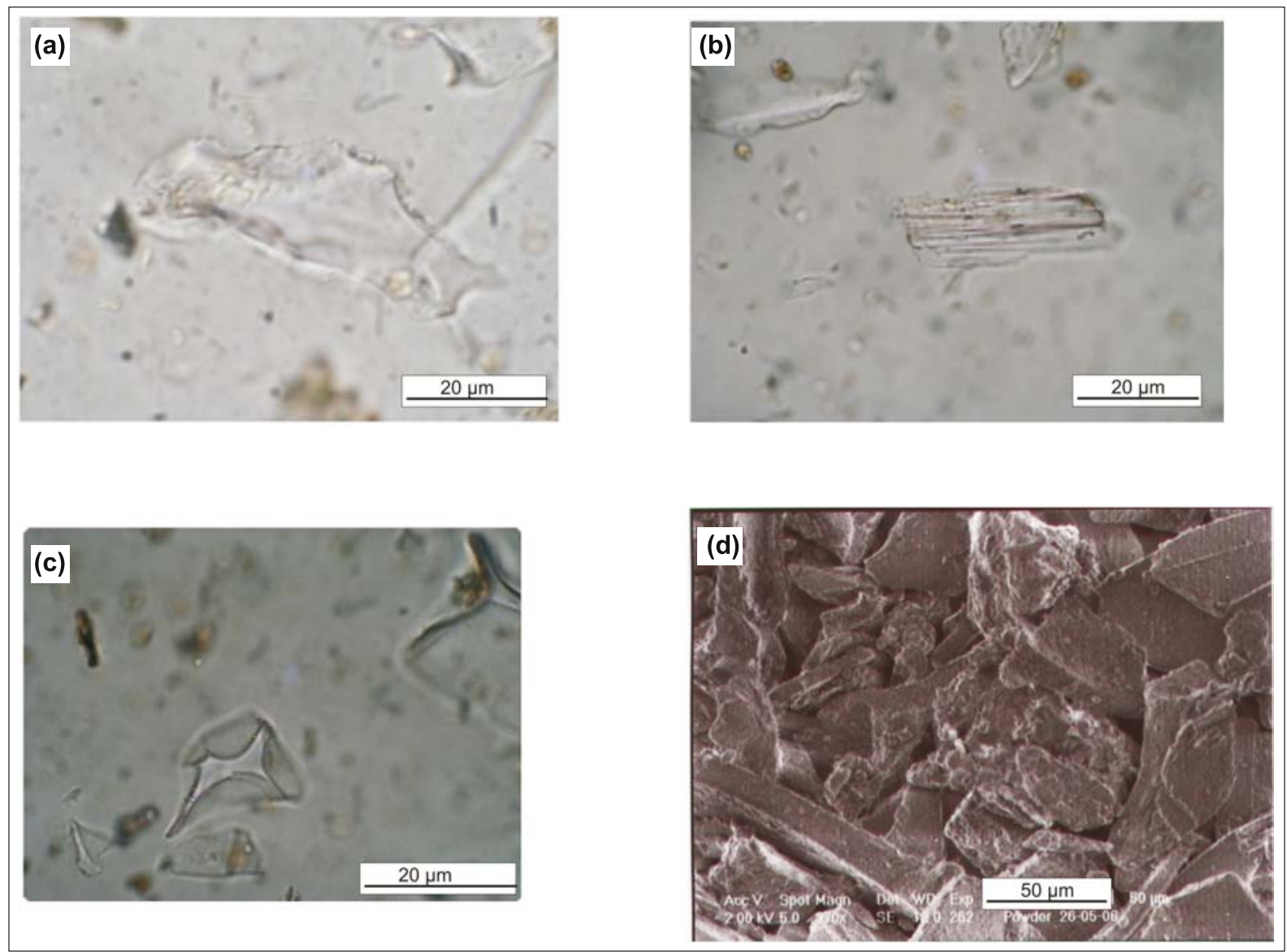

Figure 4. SEM photographs of: (a) Glass shard showing typical conchoidal fracture. (b) Light, porous pumice shard consisting of parallel vesicles seen as long stretched thin capillary tube. (c) Shard showing tri-radiate junction wall of three bubbles. (d) Glass shard of different size and shape showing smooth and conchoidal surface.

Table 1. Table showing comparison of major oxides in the Tejpur sample with those of Gunawara-Narmada Ash, Kukadi River, Son Valley and Toba Tuff of Sumatra.

\begin{tabular}{|c|c|c|c|c|c|c|c|c|c|c|}
\hline Localities & $\mathrm{SiO}_{2}$ & $\mathrm{TiO}_{2}$ & $\mathrm{Al}_{2} \mathrm{O}_{3}$ & $\mathrm{Fe}_{2} \mathrm{O}_{3}(\mathrm{~T})$ & $\mathrm{MgO}$ & $\mathrm{MnO}$ & $\mathrm{CaO}$ & $\mathrm{Na}_{2} \mathrm{O}$ & $\mathrm{K}_{2} \mathrm{O}$ & Total \\
\hline $\begin{array}{l}\text { Madhumati River } \\
\text { (Tejpur) }\end{array}$ & 71.15 & 0.48 & 13.23 & 3.47 & 1.4 & 0.09 & 1.54 & 2.53 & 3.52 & 97.4 \\
\hline $\begin{array}{l}\text { Guruwara-Narmada Ash } \\
\text { (Acharyya and Basu 1993) }\end{array}$ & 68.18 & 0.67 & 15.90 & 5.01 & 0.57 & 0.09 & 5.58 & 1.82 & 2.28 & 100 \\
\hline $\begin{array}{l}\text { Kukadi River (Bori) } \\
\text { (Shane et al 1995) }\end{array}$ & 77.00 & 0.05 & 12.60 & $0.89(\mathrm{FeO})$ & 0.06 & 0.07 & 0.76 & 3.35 & 5.04 & 99.8 \\
\hline $\begin{array}{l}\text { Son Valley } \\
\text { (Shane et al 1995) }\end{array}$ & 77.22 & 0.05 & 12.53 & $0.94(\mathrm{FeO})$ & 0.05 & 0.06 & 0.73 & 3.18 & 5.06 & 99.8 \\
\hline $\begin{array}{l}\text { Toba Tuff Sumatra } \\
\text { Sample } 70 \text { (Chesner 1998) }\end{array}$ & 70.36 & 0.46 & 15.00 & 3.32 & 0.74 & 0.08 & 2.80 & 3.45 & 3.61 & 99.8 \\
\hline
\end{tabular}

Sumatra (Shane et al 1995; Acharyya and Basu 1993 and Chesner 1998). When compared with the rare/trace element values of ash at Tejpur and of other places (table 2) it is found that the Madhumati samples show values closer to Kukadi River and Bori. Values of Son Valley are slightly different from the values of these three localities. A strong negative $\mathrm{Eu}$ anomaly (figure 5A and $\mathrm{B}$ ) is also comparable with other continental Indian findings (Schulz et al 2002; Westgate et al 1998; Chesner and Ettlinger 1989; Pattan et al 2001 and Song et al 2000).

The ash has been recognized as Younger Toba Tuff (YTT) by its lower light REE (La, Ce, Pr, Nd, $\mathrm{Sm}$ ) content and higher heavy REE (Ho, Er, Tm, $\mathrm{Yb}, \mathrm{Lu}$ ) content and a larger Eu anomaly (table 2). 
Table 2. Trace and major element compositions including REE of Tejpur sample and those of Kukadi River, Son Valley, Bori place and YTT of Toba Caldera.

\begin{tabular}{|c|c|c|c|c|c|}
\hline Elements & $\begin{array}{l}\text { Madhumati } \\
\text { River } \\
\text { (Tejpur) }\end{array}$ & $\begin{array}{c}\text { Kukadi River } \\
\text { (Bori) } \\
\text { (Korisettar } \\
\text { et al 1989) }\end{array}$ & $\begin{array}{c}\text { Son Valley } \\
\text { (Acharyya and } \\
\text { Basu 1993) }\end{array}$ & $\begin{array}{l}\text { Bori place } \\
\text { (Kukadi) } \\
\text { (Westgate } \\
\text { et al 1998) }\end{array}$ & $\begin{array}{l}\text { YTT, Toba } \\
\text { Caldera } \\
\text { (Song et al } \\
2000)\end{array}$ \\
\hline $\mathrm{Rb}$ & 182 & 213 & 220 & 214 & 265 \\
\hline $\mathrm{Sr}$ & 104 & 48 & 35 & 51 & 28 \\
\hline $\mathrm{Y}$ & 34 & 29 & 31 & 29 & 39 \\
\hline $\mathrm{Nb}$ & 10 & 14.9 & 69 & 12.3 & 12.2 \\
\hline $\mathrm{Ba}$ & 737.17 & 439 & 12 & 327 & 117 \\
\hline $\mathrm{La}$ & 32.05 & 28.4 & 271 & 24.24 & 20.35 \\
\hline $\mathrm{Ce}$ & 61.65 & 53 & 24.10 & 46 & 40 \\
\hline $\operatorname{Pr}$ & 6.44 & 5.90 & 47 & 5.25 & 4.92 \\
\hline $\mathrm{Nd}$ & 24.63 & 19.6 & 5.30 & 18.3 & 18.2 \\
\hline $\mathrm{Sm}$ & 5.57 & 4.12 & 17 & 3.95 & 4.21 \\
\hline $\mathrm{Eu}$ & 0.95 & 0.41 & 4.23 & 0.39 & 0.03 \\
\hline $\mathrm{Gd}$ & 4.48 & 3.84 & 0.35 & 4.06 & 4.92 \\
\hline $\mathrm{Tb}$ & 0.84 & 0.67 & 3.93 & 0.72 & 0.92 \\
\hline Dy & 5.36 & 4.56 & 0.67 & 4.64 & 6.25 \\
\hline Ho & 1.17 & 0.98 & 5.03 & 0.96 & 1.35 \\
\hline $\mathrm{Er}$ & 3.69 & 2.83 & 1.13 & 3.06 & 3.90 \\
\hline $\mathrm{Tm}$ & 0.57 & 0.49 & 3.20 & 0.51 & 0.77 \\
\hline $\mathrm{Yb}$ & 3.76 & 3.34 & 0.47 & 3.52 & 4.88 \\
\hline $\mathrm{Lu}$ & 0.66 & 0.57 & 4.08 & 0.59 & 0.88 \\
\hline $\mathrm{Hf}$ & - & - & 0.49 & - & 3.42 \\
\hline Th & 27.79 & 28.1 & 28 & 26.2 & 30.3 \\
\hline $\mathrm{U}$ & 4.30 & 4.99 & 5.07 & 4.84 & 6.04 \\
\hline
\end{tabular}

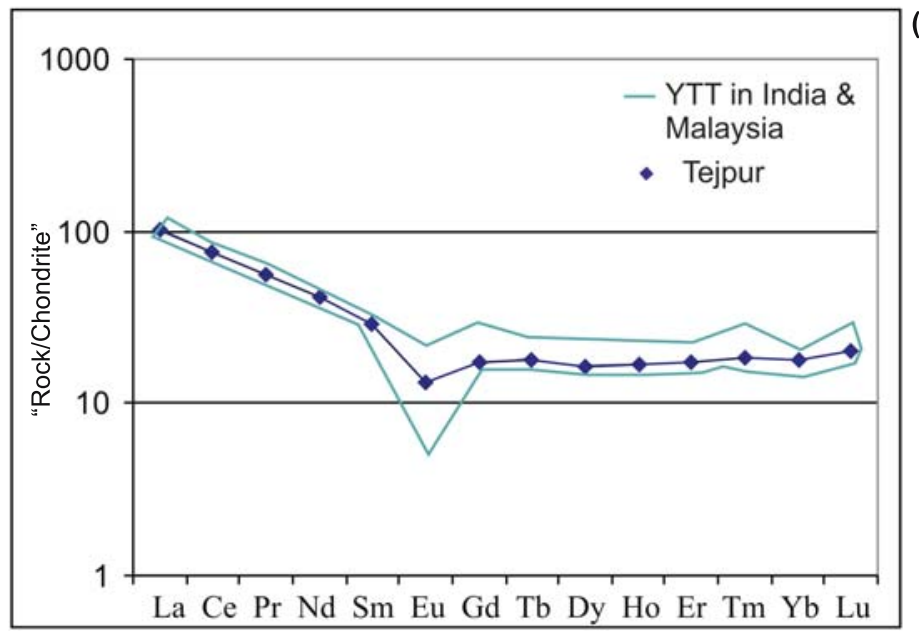

(A)

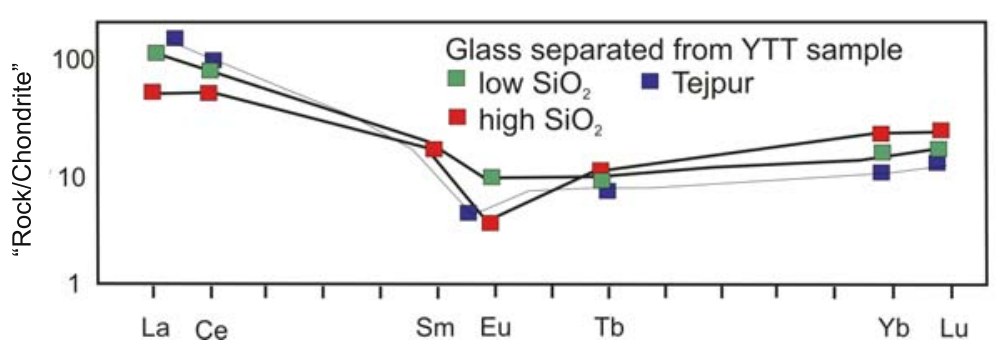

(B)

Figure 5. (A) Chondrite normalized (after Masuda et al 1973) REE pattern of ash sample from the Tejpur showing strong negative Eu-anomaly, area enclosed within blue line indicates compositional range of the distal YTT found in India and Malaysia (Westgate et al 1998). (B) REE plot of Toba samples, normalized to chondrite. Red and green boxes represent glasses separated from high- and low-SiO 2 YTT pumice samples (from Chesner and Ettlinger 1989). Blue box represents Tejpur sample. 
The highly silicic nature of the ash of the Tejpur sample is very typical of the rhyolite and closely resembles that of Toba ash of Indonesia. $\mathrm{Al}_{2} \mathrm{O}_{3}$ value of $13.23 \%$ is also very close to that of Toba ash (Ninkovich et al 1978).

\section{Discussion and conclusion}

The Toba volcanic event is one of the largest eruptions during the Quaternary (Schulz et al 2002). This volcanic mega eruption (Rose and Chesner 1987, 1990; Knight et al 1986; Acharyya and Basu 1993) occurred in the Indonesian archipelago on northern Sumatra some 70,000 years ago during a major shift in global climatic conditions from interglacial marine isotopic stage (MIS) 5 to glacial MIS 4 (Ninkovich et al 1978). More than two orders of magnitude larger than any historical eruption, Toba has been estimated to produce at least $3000 \mathrm{~km}^{2}$ of dense rock equivalent rhyolite magma $\left(7 \times 10^{15}\right)$ and more than $800 \mathrm{~km}^{3}$ of ash (Viseras and Fernandez 1995). It is estimated that at least $1 \%$ of the Earth was covered by more than $10 \mathrm{~cm}$ of ash known as Youngest Toba Tuff (YTT). The widespread tephra bed is reported from eastern and western parts of the Indian subcontinent (Acharyya and Basu 1993; Ninkovich et al 1978 and Chesner et al 1991) to the Arabian Sea (Schulz et al 1998), Indian Ocean (Pattan et al 1999) and also to the south China Sea (Bühring et al 2000 and Song et al 2000). The Toba event is believed to have a potential magnitude relevant to the global climate system (Singurdsson 1990) and has been held responsible for the shift to glacial climate (Chesner et al 1991; Rampino and Self 1992, 1993). However, evidence for a Toba triggered volcanic winter is ambiguous (Schulz et al 2002).

The ash found in the Madhumati River section at Tejpur has shown a greater percentage of bubble wall shard as compared to pumice shard. Rose and Chesner (1987) have pointed to the high drag coefficient of the bubble wall shard, which resulted in its preferential dispersal over great distances. According to them, the Toba magma had a high crystal content and thus a greater number of favourable sites where spherical vesicles could form; and probably this led to the large amount of bubble wall shards in the Toba ash. According to Izett et al (1981) pumice shard develop from relatively highly viscous rhyolitic magmas with temperature $<850^{\circ} \mathrm{C}$, whereas the bubble wall and bubble junction shards develop from lower viscosity rhyolitic magmas at temperature $>850^{\circ} \mathrm{C}$. The morphology suggests ash to be of Younger Toba Tuff of Indonesian origin. The geochemical data strongly suggest that the ash found in Madhumati River basin is associated with the Toba mega eruption of $\sim 74$ ka.
The sediment succession exposed in the Madhumati River basin is correlatable to the sediment sequence of the $\mathrm{S}_{2}$ surface of the lower Narmada basin (Chamyal et al 2002). The Thermoluminescence (TL) dating of the lower part of the exposed sediment succession of this surface at Tilakwada, in the lower Narmada basin has yielded an age of $<90 \mathrm{ka}$ (Chamyal et al 2002). This correlates very well with the ash found in almost the middle part of the correlatable succession in the Madhumati River basin. The middle part of the sedimentary unit of Madhumati River points towards a low energy weak fluvial regime during the deposition of these sediments. The change in sediment characteristics from coarse to fine and from lower unit to middle unit also indicates towards the climatic fluctuations during this time. This is also supported by Kale et al (2004) in their studies on ash associated alluvial sediments of Deccan Trap region of India. According to them during and after Toba event the monsoonal climate was drier and river discharges were depleted. The Toba event occurred during MIS 5-4 transition and the change in depositional style of the sediment succession at Tejpur from coarse to fine points to the climatic changes.

The present finding of Younger Toba Tuff at western continental margin further enlarges the estimated area and volume of fall out of Toba eruption. It requires further re-assessment of the volume of ash and its palaeoclimatic implications. Chronological studies of this ash bed in future could help establishing a precise time-controlled stratigraphy of the Quaternary sediments of lower Narmada basin.

\section{Acknowledgements}

The author is grateful to Prof. L S Chamyal for critically going through the manuscript. Dr. Jayant $\mathrm{K}$ Tripathi is thanked for carrying out chemical analysis of the sample and for useful suggestions. Reviews by the referees have been useful in improving the quality of the paper. The author would like to acknowledge Department of Science and Technology for funding in the form of research grant no. SR/FTP/ES-53/2003.

\section{References}

Acharyya S K and Basu P K 1993 Toba ash on the Indian subcontinent and its implications for correlation of late Pleistocene alluvium; Quat. Res. 40 10-19.

Agarwal G C 1986 Structure and tectonics of exposed Tertiary rocks between Narmada and Kim Rivers in south Gujarat; J. Geol. Soc. India 27 531-542.

Basu P K, Biswas S and Acharyya S K 1989 Late Quaternary ash beds from Son and Narmada basins, Madhya Pradesh; Indian Minerals 41 66-72. 
Biswas S, Basu P K and Sarkar G P 1989 Biostratigraphy of the Quaternary alluvial sediments in the central Narmada basin and the middle Son basin in eastern Madhya Pradesh; Unpubl. Report Geol. Surv. Ind. 38p.

Bühring C, Sarnthein M and Leg 184, Shipyard Scientific Party 2000. Toba ash layer in the south China Sea: evidence for contrasting wind directions during eruption Ca. 74 ka; Geology 28 275-278.

Calvache M L, Viseras C and Fernandez J 1997 Controls on fan developments - evidence from fan morphology and sedimentology, Sierra Neveda, Spain; Geomorphology 21 69-84.

Chamyal L S, Maurya D M, Bhandari S and Rachna Raj 2002 Late Quaternary geomorphic evolution of the lower Narmada valley, Western India: implications for neotectonic activity along Narmada-Son Fault; Geomorphology 46 177-202.

Chesner C A 1998 Petrogenesis of the Toba Tuffs, Sumatra, Indonesia; J. Petrol. 39 397-438.

Chesner C A and Ettlinger A D 1989 Composition of volcanic allanite from the Toba Tuffs, Sumatra, Indonesia; Amer. Mineral. 74 750-758.

Chesner C A, Rose W I, Drake A D R and Westgate J A 1991 Eruptive history of Earth's largest Quaternary caldera (Toba, Indonesia) clarified; Geology 19 200-203.

Devdas V and Meshram S N 1991 Search for Quaternary ash bed in the Quaternary basins of Orissa; Records Geol. Surv. Ind. 124 40-42.

Godin P D 1991 Fining upward cycles in the sandy braided River deposits of the West water canyon Member (Upper Jurassic), Morrison Formation, New Mexico; Sedim. Geol. 70 61-82.

Izett G A, Obradovich J D, Nasser C W and Cebula G T 1981 Potassium Argon and fission track ages of Cerro Tole do rhyolite tephra in the Jamez mountain New Mexico; In: Short contribution to isotope research in the western United States; U. S. Geol. Surv. Prof. Pap. II 99-D $37-43$.

Jo H R, Rhee C W and Choug S K 1997 Distinctive characteristics of a streamflow-dominated alluvial fan deposits, Sanghori area, Kyongsang Basin (early Cretaceous) southeastern Korea; Sedim. Geol. 11 51-79.

Jones A P, Tucker M E and Hart J K 1999 The description and analysis of Quaternary stratigraphic sections, Technical Guide 7; Quaternary Research Association, London, 293pp.

Kale V S, Joshi V U and Hire A S 2004 Palaeohydrological reconstructions based on analysis of a palaeochannel and Toba-Ash associated alluvial sediments in the Deccan Trap region, India; J. Geol. Soc. India 64 403-417.

Karmalkar N R, Ghate S N, Mishra S and Rajaguru S N 1998 Morphology of the volcanic ash from the Kukadi River section, Pune district, Maharashtra; J. Geol. Soc. India $51213-218$.

Knight M D, Walker G P L, Ellwood B B and Diehl J F 1986 Stratigraphy, palaeomagnetism and magnetic fabric of the Toba tuffs: constraints on the sources and eruptive styles; J. Geophys. Res. B91 10,355-10,382.

Korisettar R, Venkatesan T R, Misra S, Rajaguru S N, Somayajulu B L K, Tandon S K, Gogate V D, Ganjoo R K, Kale V S 1989 Discovery of a tephra bed in the Quaternary alluvial sediments of Pune district (Maharashtra), Peninsular India; Curr. Sci. 58 564-567.

Masuda A, Nakamura N and Tanaka T 1973 Fine structures of mutually normalized rare earth patterns of chondrites; Geochim. Cosmochim. Acta 37 239-248.
Miall A D 1996 The geology of Fluvial Deposits; (Berlin: Springer) $582 \mathrm{p}$.

Miall A D 1998 Stratigraphic sequences and their chronostratigraphic correlation; J. Sedim. Petrol. 61 497-505.

Ninkovich D, Shackleton N J, Abdel-Monem A A, Obradovich J D and Izett G K 1978 K-Ar age of the late Pleistocene eruption of Toba, north Sumatra; Nature 276 574-577.

Norrish K and Hutton J T 1969 An accurate X-ray spectrographic method for the analysis of a wide range of geological samples; Geochim. Cosmochim. Acta 33 431-453.

Pattan J N, Shane P and Banakar V K 1999 New occurrence of youngest Toba tuff in abyssal sediments of the central Indian basin; Marine Geol. 155 243-248.

Pattan J N, Shane P, Pearce N J G, Banakar V K and Parthiban G 2001 An occurrence of $\sim 74$ ka Youngest Toba Tephra from the western continental margin of India; Curr. Sci. 80 1322-1326.

Rampino M R and Self S 1992 Volcanic winter and accelerated glaciation following the Toba super-eruption; Nature 359 50-52.

Rampino M R and Self S 1993 Climate-volcanism feedback and the Toba eruption of 74,000 years ago; Quat. Res. 40 269-280.

Rose W I and Chesner C A 1987 Dispersal of ash in the great Toba eruption; Geology 15 913-917.

Rose W I and Chesner C A 1990 Worldwide dispersal of ash and gases from the earth's largest known eruption: Toba Sumatra, 75 ka.; Palaeogeography, Palaeoclimatology, Palaeoecology (Global and Planetary Change Section) $89269-275$.

Schulz H, Von Rad U and Erlenkeuser H 1998 Correlation between Arabian Sea and Greenland climate oscillation of the past 110,000 years; Science 393 54-57.

Schulz H, Emeis K Ch, Erlenkeuser H, Von Rad U and Rolf Ch 2002 The Toba volcanic event and interstadial/stadial climates at the marine isotopic stage 5 to 4 transition in the Northern Indian Ocean; Quat. Res. 57 22-31.

Shane P, Westgate J, Williams M and Korisettar R 1995 New Geochemical evidence for the youngest Toba Tuff in India; Quat. Res. 44 200-204.

Sigurdsson H 1990 Evidence of volcanic loading of the atmosphere and climate response; Palaeogeography Palaeoclimatology Palaeoecology 89 277-289.

Song S R, Chen C H, Lee M Y, Yang T F, Iizuka Y and Wei K Y 2000 Newly discovered eastern dispersal of the younger Toba tuff; Marine Geology 167 303-312.

Viseras C and Fernandez J 1995 The role of erosion and deposition in the construction of alluvial fan sequences in the Guadix Formation (SE Spain); Geologie en Mijnbouw 21-33.

Westgate J, Shane P, Pearce N, Perkins W, Korisettar R, Chesner C, Williams M and Acharyya S K 1998 All Toba tephra occurrences across peninsular India belong to the 75,000 years B.P. eruption; Quat. Res. 50 107-112.

William M A J and Royce K 1982 Quaternary geology of the middle Son valley, north central India: implications for prehistoric Archaeology; Palaeogeography Palaeclimatology Palaeoecology 38 139-162.

William M A J and Clarke M F 1984 Late Quaternary environments in north-central India; Nature 308 633-635.

William M A J and Clarke M F 1995 Quaternary geology and pre-historic environments in the Son and Belan valleys, north central India; Geol. Soc. India Memoir 32 $282-308$ 